\title{
31. MAJOR AND MINOR ELEMENT GEOCHEMISTRY OF INTERSTITIAL WATERS OF SITE 808, NANKAI TROUGH: AN OVERVIEW ${ }^{1}$
}

\author{
Joris M. Gieskes, ${ }^{2}$ Toshitaka Gamo, ${ }^{3}$ and Miriam Kastner $^{2}$
}

\begin{abstract}
Detailed concentration depth profiles of a number of major and minor dissolved constituents of the interstitial waters retrieved from sediments of Site 808 (Nankai Trough) have revealed that a complex set of processes has affected these distributions. Because the major purpose of the drilling program was to evaluate the role of fluids in the accretionary prism of the Nankai Trough, only the results directly relevant to this problem are summarized in this abstract. (1) Interstitial water concentrations of a number of dissolved components indicate that there is no evidence for fluid flow associated with the recent (Holocene?) fault between $340-390 \mathrm{~m}$ below seafloor (mbsf). (2) In the Shikoku Basin deposits, directly underlying the trench fill section (below $620 \mathrm{mbsf}$ ), the interstitial water profiles are characterized by a large decrease in dissolved chloride (depletion with respect to ocean water at $\sim 1150 \mathrm{mbsf}$ is about $18 \%$ ). The decrease in chloride concentration is interpreted to be the result of dehydration of clays. Only a small part of this process appears to occur in situ. The major part of the chloride decrease, however, must be due to dehydration further into the accretionary complex with the subsequent seaward advection of these fluids. Such an advection of low chloride fluids would be consistent with similar observations made in the Barbados Accretionary Prism (ODP Leg 110) and off Chile-Peru (ODPLeg 112). (3) Maxima in components associated with diagenesis of organic matter in the vicinity of the décollement suggest that an input of fluids has occurred along the zone of décollement, probably originating from the accretionary prism rather than from the deeper sediment layers.
\end{abstract}

\section{INTRODUCTION}

Fluid expulsion as a result of compaction and shortening of sediments in accretionary prisms has been shown to be of importance by various authors (Bray and Karig, 1985, 1986; Fowler et al., 1985; Moore and Biju-Duval, 1984; Von Huene and Scholl, 1991). Associated with this fluid expulsion is the venting of nutrient-rich fluids at the seafloor along fault zones and through carbonate or barite chimneys, leading to the observation of unusual biotic communities along the coast of Oregon (Kulm et al., 1986; Ritger et al., 1987) and in the Japan Trench and the Nankai Trough (Boulegue et al., 1987; Gamo et al., 1992; LePichon et al., 1987; Swinbanks, 1985). The mode of fluid expulsion has been modeled theoretically (Screaton et al., 1990; Shi and Wang, 1985; 1988; Foucher et al., 1990; LePichon et al., 1990) and has been inferred also from considerations of geochemical and geothermal anomalies (Vrolijk et al., 1991). Investigations of the fluid geochemistry have been shown to be of great usefulness in setting limitations to the mode of fluid expulsion as well as to the processes involved in the generation of observed geochemical anomalies in the fluid chemistry (Gieskes et al., 1989, Gieskes, Blanc, et al., 1990; Gieskes, Vrolijk, and Blanc, 1990; Kastner et al., 1990, 1991; Vrolijk et al., 1990, 1991).

In this paper a discussion is presented of the major- and minorelement geochemistry of pore fluids obtained at various sites in the Nankai Trough and the Shikoku Basin, with particular reference to Site 808 drilled during Leg 131 of the Ocean Drilling Program (ODP). Particular attention is given to possible changes in the geochemistry of the fluids, which may indicate the presence of fluid flow.

\section{PREVIOUS WORK}

Drilling of Site 808 occupied all available time of Leg 131, and for these reasons no direct nearby reference site is available to make

\footnotetext{
${ }^{1}$ Hill, I.A., Taira, A., Firth, J.V., et al., 1993. Proc. ODP, Sci. Results, 131: College Station, TX (Ocean Drilling Program).

${ }^{2}$ Scripps Institution of Oceanography, La Jolla, CA 92093, U.S.A.

${ }^{3}$ Ocean Research Institute, University of Tokyo, Japan.
}

comparisons of observed geochemistries of the interstitial waters. For these reasons, therefore, it may be useful to present a brief description of the observations on interstitial fluid chemistry in the various sites drilled previously in the Nankai Trough: Site 297 (Karig, Kagami, et al., 1975) and Sites 582 and 583 (Kagami, Karig, et al., 1986).

\section{Interstitial Water Chemistry of Site 297}

Site 297 was drilled in the Shikoku Basin, south of the sites drilled during Legs 87 and 131 (Karig et al., 1975; Fig. 1). Notwithstanding the relatively great distance from Site 808 , Site 297 can serve as a potential reference for the following reasons. Sedimentation rates at this site are similar to those in the Shikoku Basin section of Site 808 (Taira, Hill, Firth, et al., 1991), and the sediment section shows many similarities, including the presence of volcaniclastic sediments below 570 mbsf. The upper section between 0 and 330 mbsf indicates sedimentation rates in excess of $100 \mathrm{~m} / \mathrm{Ma}$, and this is expected to be reflected in the distribution of alkalinity and sulfate, which show extremes at $\sim 125$ mbsf (White, 1975; Fig. 2). This is principally the result of more intensive diagenesis of organic matter in this rapidly deposited section with the simultaneous effects of diminished diffusive communication with the overlying ocean. Below $300 \mathrm{mbsf}$ sulfate concentrations increase to about $8 \mathrm{mM}$. The concentration of calcium shows a minimum in the upper zone $\left(\mathrm{CaCO}_{3}\right.$ precipitation), below which a small but gradual increase occurs toward the base of the hole. Magnesium and potassium concentration profiles indicate sinks at depth, and strontium appears to have a deep source to reach concentrations about two times that of seawater. No strontium isotopes were studied in order to determine the possible source of this strontium. Site 297 is characterized by a relatively high heat flow, with temperatures at the base of the hole of $75^{\circ}-100^{\circ} \mathrm{C}$ (cf. heat-flow discussion in Site 297 report, Karig et al., 1975). Calculated $\mathrm{Na} / \mathrm{Cl}$ ratios in this hole are elevated above that of seawater.

\section{Interstitial Water Chemistry of Sites $\mathbf{5 8 2}$ and $\mathbf{5 8 3}$}

During Leg 87 two sites were drilled in the Nankai Trough, and in both sites only the rapidly deposited trench fill section of the sediment column was penetrated (Kagami, Karig, et al., 1986). 


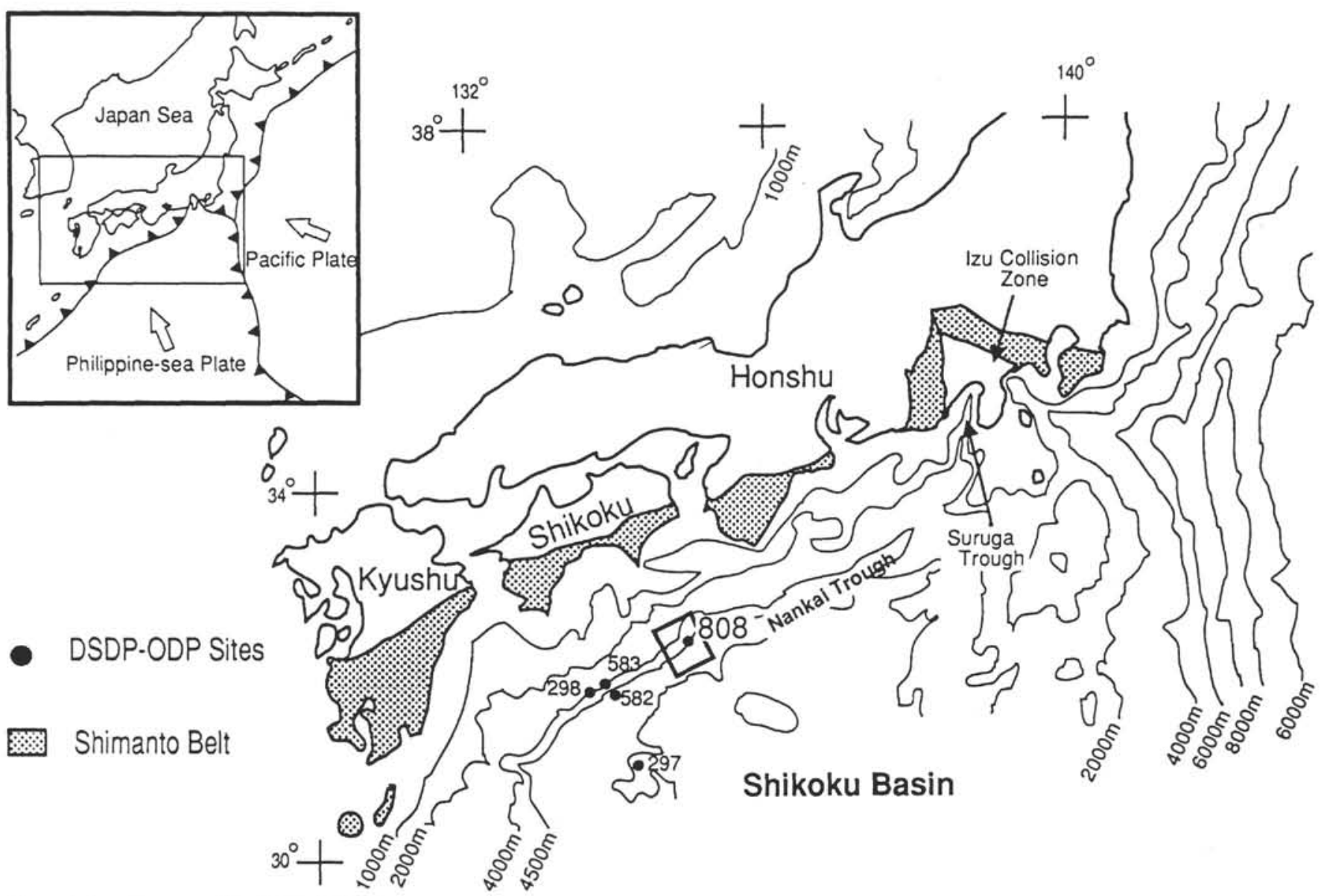

Figure 1. Location map of the Nankai Trough.

Site 582 was located about $2 \mathrm{~km}$ seaward from the deformation front. The upper $120 \mathrm{mbsf}$ are characterized by sedimentation rates of $\sim 340 \mathrm{~m} / \mathrm{Ma}$, below which the rates increase to $\sim 1000 \mathrm{~m} / \mathrm{Ma}$ to a depth of $570 \mathrm{mbsf}$. Below this depth much lower sedimentation rates occur (210-320 m/Ma) and the deepest penetrated sediments ( 749 mbsf) were $\sim 1.8$ m.y. old. Interstitial water data (Kawahata et al., 1986; Matsuhisa and Matsumoto, 1986) indicate a rapid decrease in dissolved sulfate with depth, reaching a minimum at about $150 \mathrm{mbsf}$, accompanied by a maximum in alkalinity (Fig. 3). The increase in sulfate toward the bottom of the hole appears remarkably high, especially because the entire sediment column is characterized by high sedimentation rates, which in turn most often leads to the complete removal of sulfate by sulfate-reducing bacteria. Magnesium depletion is pronounced in the upper sediment section, with a minimum at $\sim 20$ mbsf. This constituent, however, continues to decrease with depth below $\sim 200 \mathrm{mbsf}$. The decreases in magnesium can be understood best in terms of uptake of magnesium during clay mineral formation associated with the alteration of volcanic matter.

Site 583 is located at the boundary of the deformation front, with a fault zone intersecting Holes $583 \mathrm{~B},-\mathrm{C}$, and -D (seaward side). Holes $583,-\mathrm{F}$, and $-\mathrm{G}$, on the other hand, are located in the accretionary part. Though the depth distributions of alkalinity, $\delta^{18} \mathrm{O}\left(\mathrm{H}_{2} \mathrm{O}\right)$, calcium, and magnesium (Matsuhisa and Matsumoto, 1986) do indicate some scatter in the data, the concentration depth profiles indicate a much steeper decrease in $\delta^{18} \mathrm{O}\left(\mathrm{H}_{2} \mathrm{O}\right)$ and magnesium in the shallow part of the section in the accretionary prism (Fig. 4). This could possibly be related to a slow upward expulsion of fluids in this upper part of the accretionary prism. Unfortunately, the concentration depth profiles are not detailed enough to allow an estimate of the upward advection rate. Changes in magnesium and $\delta^{18} \mathrm{O}\left(\mathrm{H}_{2} \mathrm{O}\right)$ are well correlated, but the cause of this correlation is undetermined, though alteration of volcanic matter would lead to these changes.

It is apparent from the above data on Sites 297, 582 and 583, that in order to determine the nature of concentration depth profiles in this area, very detailed concentration depth profiles must be obtained, covering as many components as possible. One of the aims of the inorganic geochemistry program of Leg 131 was to obtain such detailed profiles, including major and minor constituents and isotope studies. The former are discussed here, whereas an accompanying overview paper (Kastner et al., this volume) emphasizes the results of the isotopic studies.

\section{OBSERVATIONS ON INTERSTITIAL WATERS AT SITE 808}

Site 808 consisted of three holes in which interstitial waters were obtained in great detail. The holes $(808 \mathrm{~A},-\mathrm{B},-\mathrm{C})$ are located within $\sim 200 \mathrm{~m}$ from each other, with Hole $808 \mathrm{~A}$ and $808 \mathrm{~B}$ about $150 \mathrm{~m}$ distant (Taira et al., 1991). A major thrust fault is observed in Hole $808 \mathrm{C}$ from 340 to $390 \mathrm{mbsf}$, and this fault is located at a somewhat shallower depth in Hole 808B. The lithology of the hole is summarized in Figure 5. The upper $620 \mathrm{~m}$ of the sediments accumulated at a very high sedimentation rate $(>1000 \mathrm{~m} / \mathrm{Ma})$, and they consist of trench fill turbidites. Volcanic contents increase in the section below $410 \mathrm{mbsf}$, and ash layers become important in the section between 620 and 820 mbsf (Unit IVa), below which the volcanic components decrease drastically. The lower Shikoku Basin deposits are characterized by a zone of décollement between 945 and 964 mbsf. Unit V (1243-1289.9 mbsf) overlies oceanic basement and is characterized by acidic volcaniclastic deposits. 

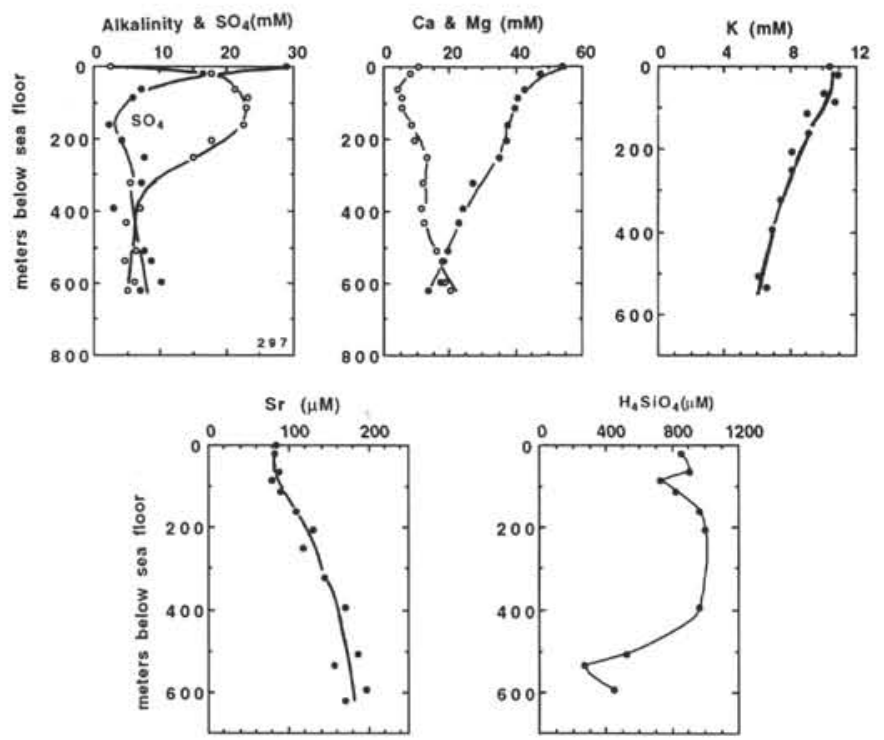

Figure 2. Interstitial water data, Site 297, DSDP Leg 31. Alkalinity: open circles; Ca: open circles; $\mathrm{Mg}$ : closed circles.

\section{Silica}

Dissolved silica concentrations (all samples obtained during room temperature squeezing) show considerable complexity (Fig. 6). However, because of the strong dependence of dissolved silica on the temperature at which the samples are extracted from the sediments (Manheim and Sayles, 1974) and because temperatures below 1000 $\mathrm{m}$ reach to over $100^{\circ} \mathrm{C}$, the actual in-situ dissolved silica concentrations may have been considerably higher. Notwithstanding this effect, relative concentration changes can still be considered as a measure of changes in lithology. Peaks and valleys in dissolved silica below 400 mbsf and to a depth of $820 \mathrm{mbsf}$ are probably the result of the presence or absence of volcanic ash in the squeezed samples, the ash layers probably having somewhat higher glass contents and thus higher dissolved silica concentrations.

Especially noteworthy are the elevated concentrations in the overpressurized zone just below the décollement. It appears that this overpressured state has led to increased silica concentrations, there being little difference in the sediment lithology just above and below the décollement.

\section{Constituents Influenced by Organic Carbon Diagenesis}

The complete depth distributions of interstitial water constituents, which are primarily affected by the decomposition of organic carbon in the sediment column, are presented in Figure 7.

Dissolved sulfate decreases rapidly in the upper $10 \mathrm{mbsf}$ to reach zero concentrations. The sediments below the sulfate reduction zone are characterized by methane generation. Sulfate remains essentially undetectable $(<1 \mathrm{mM})$ to a depth of $\sim 820 \mathrm{mbsf}$, below which a gradual increase to about $7 \mathrm{mM}$ is observed. This increase is similar to that observed in Site 297 (Fig. 2). Slightly elevated sulfate concentrations around $400 \mathrm{mbsf}$ are probably the result of a minor seawater contamination, the sediments in this depth range being characterized by low porosities and small interstitial water yields (cf. Taira, Hill, Firth, et al., 1991). Some of the variability in the sulfate data below $820 \mathrm{mbsf}$ is probably also due to minor amounts of surface seawater (drilling fluid) contamination.

Alkalinity increases are large in the first $100 \mathrm{mbsf}$, i.e., in the zone of rapid deposition of the trench apron and trench wedge sand layers (Units I and IIa). This is also the zone in which dissolved iodide,
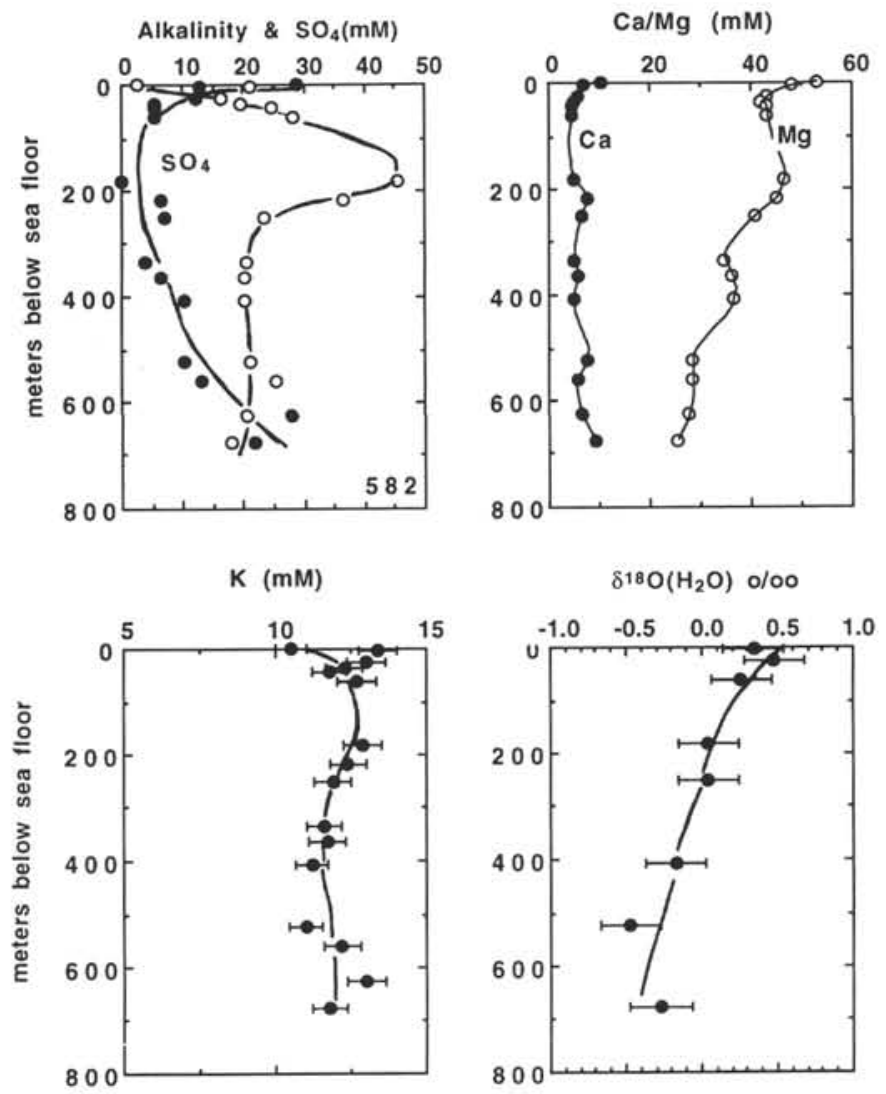

Figure 3. Interstitial water data, Site 582, DSDP Leg 87. Alkalinity: open circles.

bromide, and organic carbon (humic substances or yellow substance, YS) production are the largest (You et al., this volume).

Dissolved ammonium reaches a maximum at $\sim 150 \mathrm{mbsf}$ and rapidly diminishes toward a depth of $\sim 600 \mathrm{mbsf}$ (Unit III). The concentration reversals around the major thrust fault will be discussed below.

Below 820 mbsf alkalinity reaches a second maximum, apparently around the zone of décollement. In this depth range slightly elevated concentrations in iodide and bromide, as well as other constituents, are observed (You et al., this volume).

\section{Chloride and Alkalies}

Because of the large number of interstitial water samples it became possible to demonstrate a detailed structure in the concentration depth profile of dissolved chloride (Fig. 8). After an initial rapid increase below the surface, dissolved chloride shows a minimum at $\sim 120 \mathrm{mbsf}$. This phenomenon may be associated with the decomposition of dispersed gas hydrates, as has been observed previously in Leg 64 (Gieskes et al., 1982), Leg 66 (Gieskes et al., 1985), Legs 67 and 84 (Harrison et al., 1982; Hesse et al., 1985), and Leg 112 (Kastner et al., 1990). The gradual increase with depth in the upper $600 \mathrm{~m}$ of the sediment column is followed by a steady decrease to well below seawater concentrations, with an apparent minimum around 1100 mbsf. Below this depth an increase occurs, presumably as a result of hydration reactions in the volcanics of Unit V.

The dissolved sodium concentration pattern follows that of dissolved chloride, though concentration reversals associated with the thrust fault at $\sim 365$ mbsf mirror other anomalies associated with this zone (see below). Of interest, however, is that sodium indicates an increase that is relatively larger than the increase of chloride, thus leading to substantially higher $\mathrm{Na} / \mathrm{Cl}$ ratios $(0.92$ vs. 0.86$)$ when 

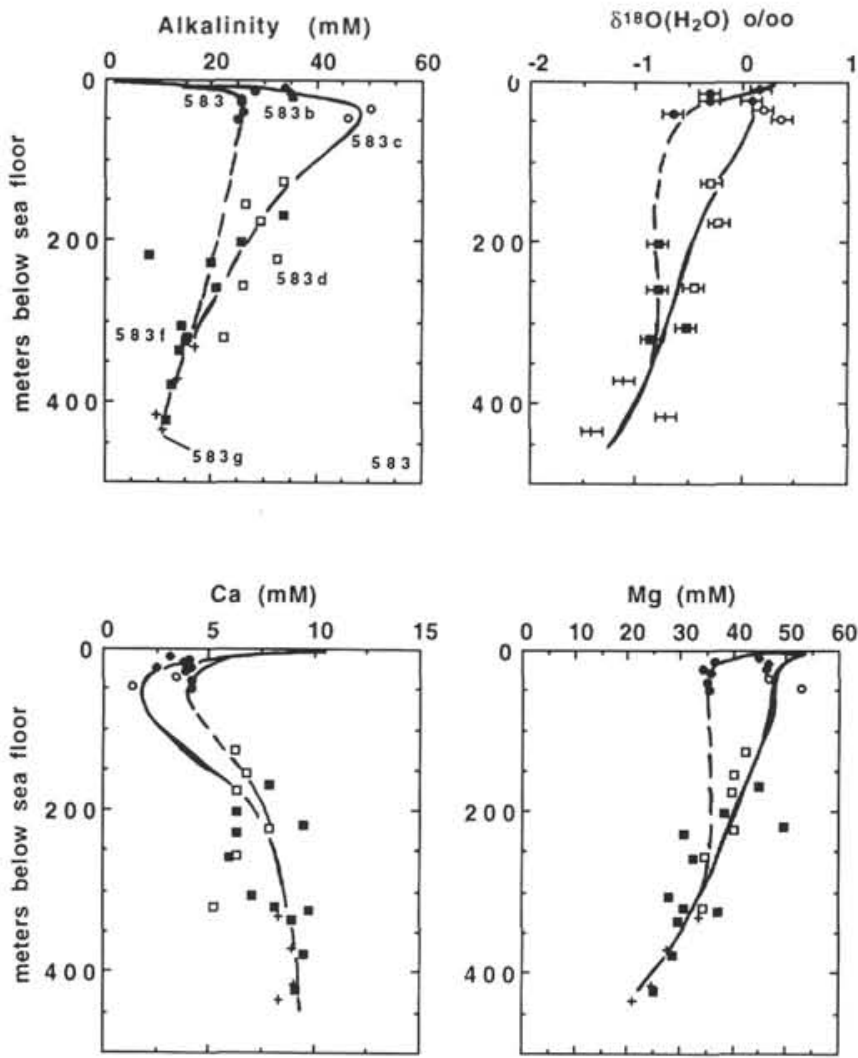

Figure 4. Interstitial water data, Site 583, DSDP Leg 87. Closed circles: 583; closed diamonds: $583 \mathrm{~B}$; closed squares: $583 \mathrm{~F}$; open circles: $583 \mathrm{C}$; open squares: $583 \mathrm{D}$; crosses: $583 \mathrm{G}$.

compared to seawater. Only below $\sim 1150$ mbsf does a decrease in $\mathrm{Na} / \mathrm{Cl}$ reflect a steep increase in calcium (see below), probably again associated with alteration reactions in Unit V, characterized by volcaniclastic deposits.

Dissolved potassium decreases rapidly below an initial shallow maximum, again showing anomalous behavior around the zone of the frontal thrust. Below $600 \mathrm{mbsf}$, concentrations rapidly diminish to concentrations $<1 \mathrm{mM}$.

Lithium concentration profiles usually indicate a behavior totally different from those of the heavier alkali metals, and Site 808 is no exception. Lithium concentrations in Holes $808 \mathrm{~A}$ and $-\mathrm{B}$ will be discussed presently, but the large increases and the variability in the concentration depth profile below 400 mbsf are evident. The data suggest distinct maxima, particularly around $750 \mathrm{mbsf}$, but also at 520 mbsf and 1020 mbsf.

\section{Alkaline Earth Elements}

The concentration-depth profiles of calcium, magnesium, and strontium indicate considerable structure (Fig. 9). Details of the profiles in the upper $600 \mathrm{mbsf}$ will be discussed in the following sections, especially the variability around the thrust fault between 340 and 390 mbsf. It is evident that below 620 mbsf magnesium disappears as a significant interstitial water component. Whether the minor concentrations of $1-2 \mathrm{mM} \mathrm{Mg}$ are real or due to slight seawater contamination is difficult to determine. Below $620 \mathrm{mbsf}$, on the other hand, dissolved calcium and strontium show increases. The largest increase in calcium occurs below $1150 \mathrm{mbsf}$ toward the volcaniclastic sediments of Unit $\mathrm{V}$. The latter increase is mirrored in an equally steep increase in strontium, but dissolved strontium shows much more detail, with minima at $760 \mathrm{mbsf}$ and at $\sim 1050 \mathrm{mbsf}$. To some extent these minima are reflected in maxima in dissolved lithium, though generally the complications in the lithium profile do not mirror those of strontium.

\section{DISCUSSION}

In this section we discuss the observations in various depth horizons of the drill site. For this purpose it is convenient to discuss first the upper few hundred meters (Holes 808A and -B); then the observations between 300 and $620 \mathrm{mbsf}$, with particular reference to the thrust fault zone; and finally the zone below $620 \mathrm{mbsf}$, with special attention to the evidence for advection of fluids into this section of the site.

\section{Holes 808A and 808B}

Though some of the concentration depth profiles in Figure 10 have already been mentioned before, the detail in the profiles of Figure 10 warrants further discussion. The dashed horizontal line in Figure 10 indicates the bottom of the trench-fill sandy turbidites (bottom of Unit Па).

The rapidly increasing alkalinity profile indicates a small minimum at $\sim 20$ mbsf. This minimum is accompanied by a minimum in calcium, as well as in magnesium and strontium. The chloride concentration indicates a maximum at this depth, with an increase of about $4 \%$ over that of the overlying ocean waters. Similarly sodium and $\mathrm{Na} / \mathrm{Cl}$ indicate maxima at $\sim 20 \mathrm{mbsf}$. On the other hand, lithium shows a very rapid decrease to very low concentrations in the upper sediments. The combination of these observations suggests that not only carbonate precipitation (decrease in $\mathrm{Ca}$ ), but also alteration of igneous (volcanic?) material is involved in causing the observed concentration changes. This is particularly evident from the low values of $\delta^{180}\left(\mathrm{H}_{2} \mathrm{O}\right)$ as well as of the ${ }^{87} \mathrm{Sr} /{ }^{86} \mathrm{Sr}$ ratio of dissolved strontium in this interval (Kastner et al., this volume). The chloride concentration increases also suggest the formation of hydrated minerals (sink for $\mathrm{Mg}$ and $\mathrm{Sr}$, as well as for $\mathrm{Li}$ ?). The rapid rise in the $\mathrm{Na} / \mathrm{Cl}$ ratio would then imply the release of sodium during these alteration reactions.

The data for most constituents indicate extremes around $120 \mathrm{mbsf}$, which also constitutes the transition of Hole 808A to 808B. The relatively long distance between these holes $(\sim 150 \mathrm{~m})$ attests to the lateral homogeneity of the interstitial water concentrations in this area. It is tempting to explain the minimum in chloride at about $120 \mathrm{mbsf}$ in terms of decomposition of dispersed hydrates during the core retrieval process. Such chloride decreases have been observed in the sediments of the Mid-American Trench, where chloride decreases were accompanied by increases in $\delta^{18} \mathrm{O}$ of the interstitial waters (Harrison et al., 1982; Hesse et al., 1985). This, of course, would not necessarily explain the relatively large decreases in calcium and strontium in this zone, unless carbonate precipitation would be the cause. The latter process, however, is not reflected in the alkalinity profile.

The data for dissolved silica (Fig. 10) indicate a distinct increase in dissolved silica below 180 mbsf. Associated with this is a sharp maximum in lithium, and both dissolved calcium and magnesium indicate potential inputs and removals in the same depth horizon. This is probably related to a diagenetic front in the sediments, in which silica transformations are associated with reactions involving igneous materials (Kastner and Gieskes, 1976).

\section{Thrust Fault between 340 and 390 mbsf}

Many of the concentration depth profiles depicted in Figs. 7, 8, and 9 indicate concentration reversals in the depth range of $340-390$ mbsf, e.g., $\mathrm{NH} 4, \mathrm{I}, \mathrm{Br}$ (Fig. 7), $\mathrm{Na}, \mathrm{K}, \mathrm{Li}$ (Fig. 8), and $\mathrm{Ca}$ and $\mathrm{Mg}$ (Fig. 9). This phenomenon is demonstrated for $\mathrm{Ca}, \mathrm{Mg}$, and $\mathrm{Li}$ in Figure 11 . At a depth of $350 \mathrm{mbsf}$ concentrations of the various constituents are equal to those at about $440 \mathrm{mbsf}$, suggesting a vertical displacement of about $90 \mathrm{~m}$ associated with the frontal thrust in Hole 808C. The concentration depth profiles show strong symmetries, which suggest that in-situ reactions have only a small effect on the profiles. The concentration reversals are the result not only of the emplacement of 

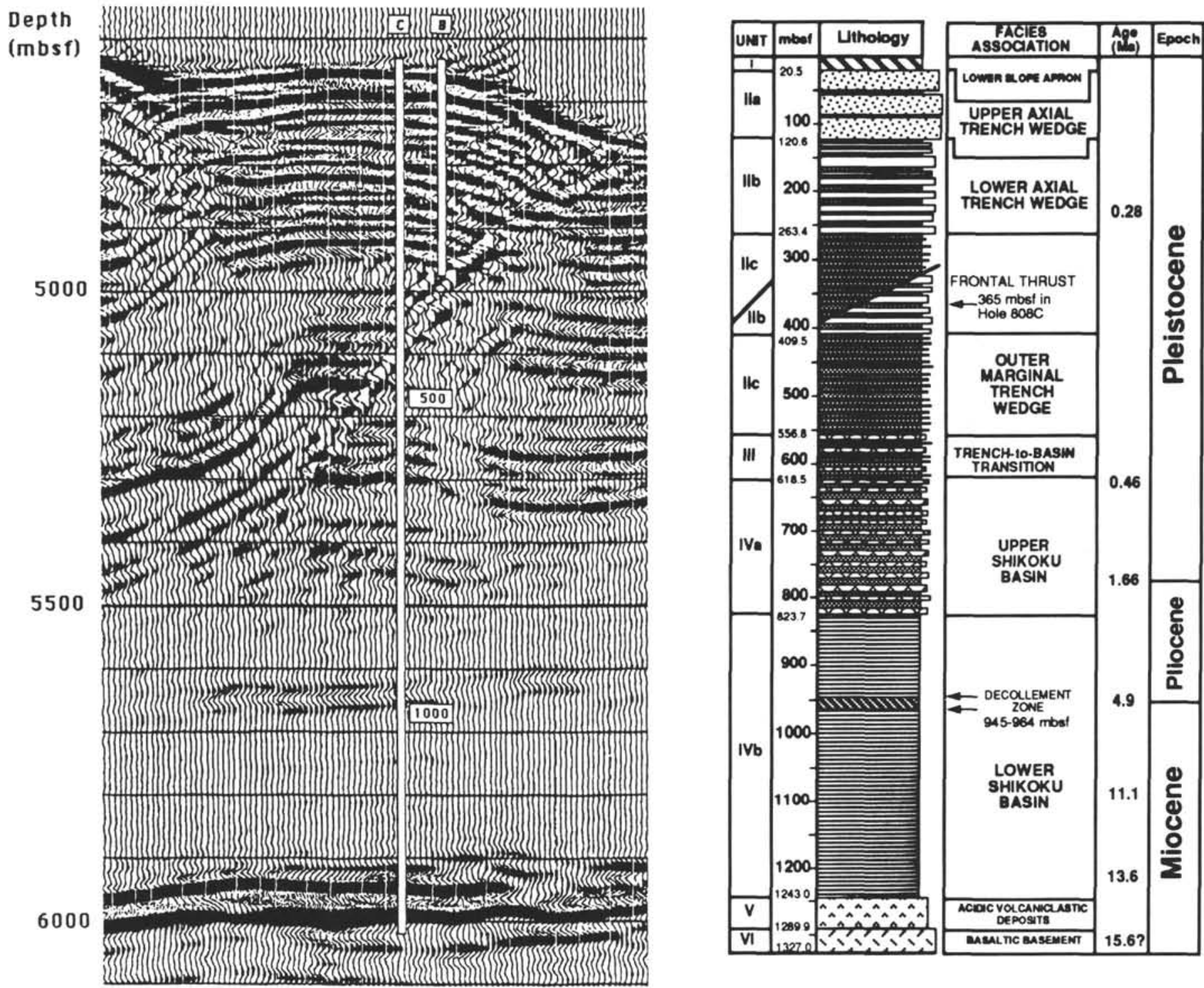

Figure 5. Structure and lithology, Site 808.

deeper sediments above $365 \mathrm{mbsf}$, but also of the associated folding processes (Taira, Hill, Firth, et al., 1991). Emplacement of the deeper sediments above the sediments at $\sim 350$ mbsf has been recent enough not to allow diffusive exchange to eradicate the concentration anomalies (with a diffusion coefficient of $5.10-6 \mathrm{~cm}^{2} / \mathrm{s}$ and a time of folding of $50,000 \mathrm{yr}$, the diffusive pathlength (2Dt) ${ }^{1 / 2}$ is about $40 \mathrm{~m}$, i.e., the thickness of the thrust zone). In addition, porosity depth changes between 300 and 500 mbsf are minimal (Taira, Hill, Firth, et al., 1991; Bruckmann et al., this volume), so that there is no large-scale expulsion of fluids associated with the thrusting process at this location. The absence of any anomaly in dissolved chloride in this zone also suggests that no contribution of fluid flow from deeper in the sediment section is detectable.

\section{Shikoku Basin Sediments}

The most important observation below $~ 600 \mathrm{mbsf}$ is the distinct decrease in chloride concentrations (Fig. 8), indicating a broad minimum of $~ 450 \mathrm{mM}$ at about 1100 mbsf. In part, this minimum may be induced by reactions associated with the underlying volcaniclastics, whose hydration appears to lead to the increase in dissolved chloride below 1100 mbsf. The cause of the chloride depletion has been discussed for other accretionary prisms (Gieskes et al., 1989; Vrolijk et al., 1990, 1991; Kastner et al., 1991), and generally it is agreed that clay mineral dehydration is a viable explanation for this phenomenon (Burst, 1969; Perry and Hower, 1970; Yeh and Savin, 1977). Certainly the temperatures prevailing below $600 \mathrm{mbsf}\left(\mathrm{T}>60^{\circ} \mathrm{C}\right.$ to $120^{\circ} \mathrm{C}$ at the bottom of the hole) are sufficiently high to allow this process to occur in situ. However, there is only limited evidence for a conversion of smectite to illite (Taira, Hill, Firth, et al., 1991; Underwood et al., this volume), and typically for a sediment with $>50 \%$ smectite and a porosity of $30 \%$, a recrystallization of more than $50 \%$ of the smectite is necessary to lower the chloride concentration to $450 \mathrm{mM}$ from the seawater value of $\sim 550 \mathrm{mM}$ (Vrolijk et al., 1991). Thus an advective input of low chloride fluids from deeper into the accretionary prism or from the subducting sediments appears to be required.

Sodium concentrations decrease with those in chloride below 600 mbsf, but unlike the increase in chloride below $1100 \mathrm{mbsf}$, no increase in sodium is observed in this depth range. However, a decrease in $\mathrm{Na} / \mathrm{Cl}$ mirrors the sharp increases in calcium and strontium (Fig. 9) below $1100 \mathrm{mbsf}$. Of importance is the observation that $\mathrm{Na} / \mathrm{Cl}$ remains essentially constant to a depth of $1100 \mathrm{mbsf}$. Any fluid emplaced advectively below the décollement, therefore, must be characterized 


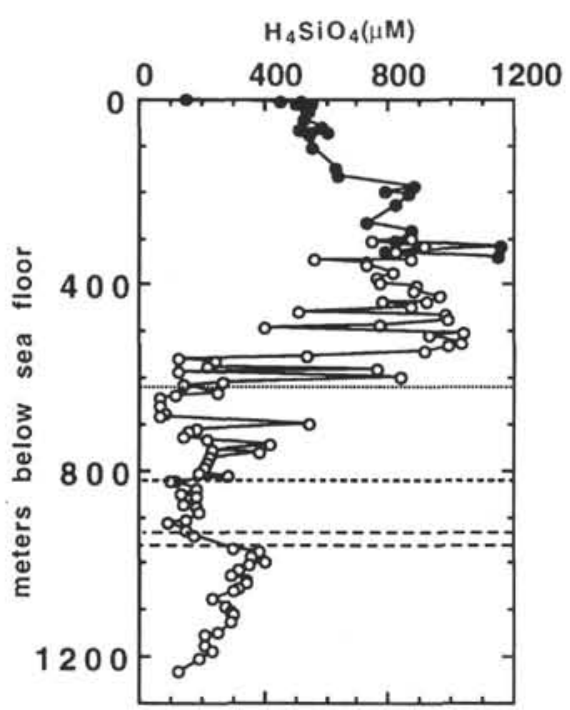

Figure 6. Dissolved silica, Site 808. Closed symbols: Holes 808A and 808B; open circles: Hole 808C; dotted line: boundary between trench fill deposits and Shikoku Basin sediments; dashed line: transition to lower Shikoku Basin sediments; broadly dashed lines: zone of décollement, 945-964 mbsf.

by $\mathrm{Na} / \mathrm{Cl}$ ratios similar to those prevailing in the entire hole. It is of interest to note that calculated $\mathrm{Na} / \mathrm{Cl}$ ratios in Site 297 are also elevated above seawater values.

Below $820 \mathrm{mbsf}$ an increase in dissolved sulfate is apparent all the way to the bottom of the hole. Again, if the low chloride fluids have been emplaced by horizontal advective flow from further into the accretionary complex, then this fluid must have been characterized by somewhat elevated sulfate concentrations. In Site 297 the deeper sediments are also characterized by elevated sulfate concentrations, suggesting that the source of the low chloride fluid must be located in the deeper part of the accretionary complex, or, more likely, in the sediments below the décollement.

The structure in the concentration depth profiles of calcium, strontium, and lithium is complex in the Shikoku Basin sediment section (Fig. 12). Whereas the most striking feature in the calcium profile is the large concentration increase below $1150 \mathrm{mbsf}$, the profiles in strontium and lithium indicate pronounced minima and maxima that appear unrelated to each other or to the calcium profile. In the lower part of the volcanic-rich zone between 620 and $820 \mathrm{mbsf}$, a small maximum in calcium is accompanied by a minimum in strontium and a pronounced maximum in lithium. This could be explained in terms of the alteration of volcanic ash, but this needs corroboration from $\delta^{18} \mathrm{O}\left(\mathrm{H}_{2} \mathrm{O}\right)$ and ${ }^{87} \mathrm{Sr}{ }^{86} \mathrm{Sr}$ data. Between $820 \mathrm{mbsf}$ and about 1150 mbsf, sharp increases in both calcium and strontium are observed, but without significant correlation to each other. Neither the calcium nor the strontium profiles appear to be the result of simple diffusive communication from greater depths and thus the profiles appear to be affected by reactive and/or advective processes, with strontium indicating a broad maximum centering along the décollement. Only below $\sim 1150$ mbsf is the correlation between calcium and strontium linear with a slope of $\delta \mathrm{Sr} / \delta \mathrm{Ca}=5.3 \times 10^{-3}$.

Isotope information on ${ }^{87} \mathrm{Sr} /{ }^{86} \mathrm{Sr}$ of dissolved strontium as well as on $\delta^{18} \mathrm{O}\left(\mathrm{H}_{2} \mathrm{O}\right)$ and $\delta \mathrm{D}\left(\mathrm{H}_{2} \mathrm{O}\right)$ suggests that a major input of low-chloride fluids below the zone of décollement is due to advection of such fluids and that the chemical signals can best be understood in terms of clay mineral dehydration (Kastner et al., this volume). We submit that the principal input occurred in the $1100 \mathrm{mbsf}$ horizon and that in addition to lateral fluid advection, vertical movement of fluids, with associated mixing, occurred to at least the $850 \mathrm{mbsf}$ level. Typically a minimum in chloride occurs at $\sim 1100 \mathrm{mbsf}$, and above $\sim 850 \mathrm{mbsf}$ the $\mathrm{Cl}$-profile is essentially diffusive in character. At the same time,
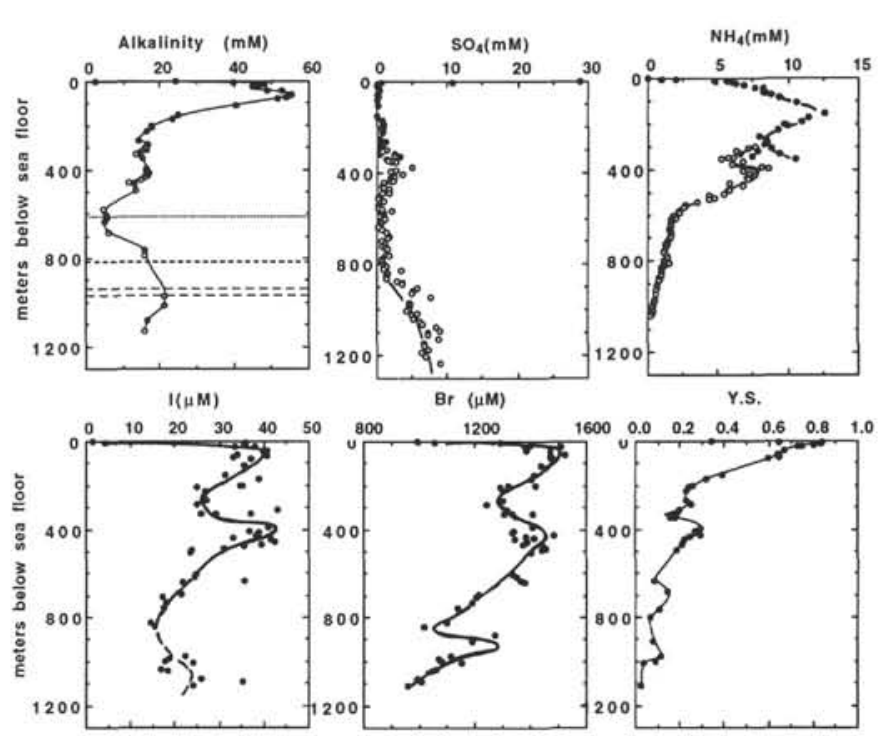

Figure 7. Distribution of biogenically derived constituents, Site 808. Closed circles in alkalinity, sulfate, and ammonia: $808 \mathrm{~A}$ and -B; horizontal lines as in Figure 6 .

however, extremes in the concentration-depth profiles of alkalinity, bromide, iodide(?), boron, laser-induced fluorescence of organic carbon, and manganese (You et al., this volume) occur in the zone of décollement (Figs. 7 and 13). These maxima are not strongly mirrored in chloride, and, therefore, if fluid advection were to be responsible for these maxima as suggested by You et al. (this volume), then the origin of these fluids should be quite different from those below the décollement, which are not associated with similar extremes. The signal in the zone of décollement appears to have a much stronger imprint of reactions involving organic matter. The latter observation suggests a potential origin from within the accretionary wedge rather than from the deeper Shikoku Basin sediments. Within the complexity of fluid expulsions associated with the subduction and accretionary processes it should not be surprising to observe fluids of different origin and nature. Similar conclusions were reached for the advected fluids in the Barbados Accretionary Transect of Leg 110 (Vrolijk et al., 1991).

\section{CONCLUSIONS}

Distributions of major and minor constituents of the interstitial waters in Site 808 on the accretionary wedge of the Nankai Trough have revealed a large degree of complexity, but several processes that affect these distributions have been identified:

1. In the upper part of the sediment column the alteration of igneous material explains the increase in dissolved chloride and the simultaneous increase in the $\mathrm{Na} / \mathrm{Cl}$ ratio-this process is also inferred from the uptake of magnesium and the lowered values of $\delta^{18} \mathrm{O}\left(\mathrm{H}_{2} \mathrm{O}\right)$ and the lower than contemporaneous ${ }^{87} \mathrm{Sr} /{ }^{86} \mathrm{Sr}$ ratio of dissolved strontium.

2. At a depth of $\sim 190 \mathrm{mbsf}$ subtle changes in calcium, magnesium, lithium, and dissolved silica gradients indicate the presence of a diagenetic front, which may be associated with silica diagenesis and the alteration of volcanic material.

3. Concentration reversals in many of the dissolved constituents occur between 340 and 390 mbsf and are associated with the major thrust fault that occurs in Hole $808 \mathrm{C}$ centered at $\sim 365 \mathrm{mbsf}$. The data suggest that no fluid flow is associated with this fault, at least not in the sections sampled in Holes $808 \mathrm{~B}$ and $808 \mathrm{C}$. 


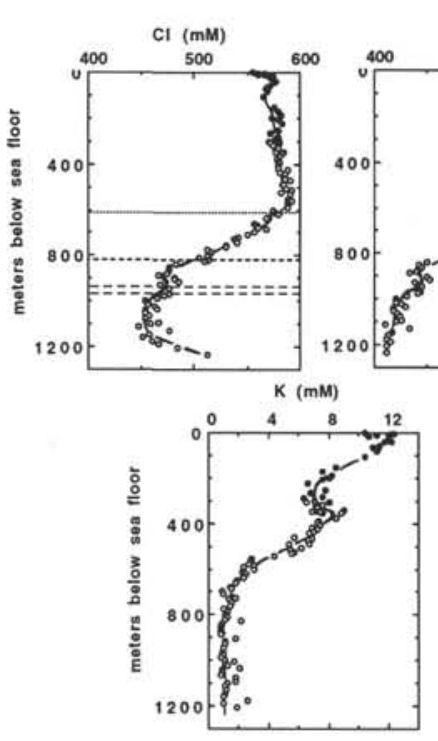

\section{$\mathrm{Na}(\mathrm{mM})$}
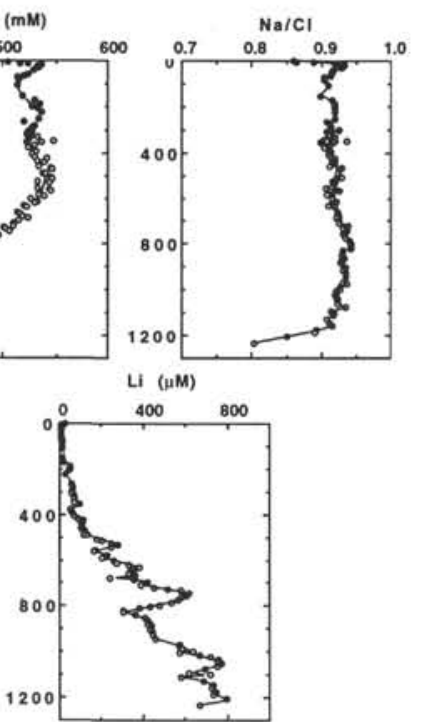

Figure 8. Chloride and alkali metals in interstitial water, Site 808. Closed circles: 808A and -B; open circles: 808C; horizontal lines as in Figure 6.

4. Lowered chloride concentrations below $620 \mathrm{mbsf}$, in the Shikoku Basin hemipelagic deposits, are, in part, due to in-situ dehydration of clay minerals, but more importantly to advection of fluids from further beneath the accretionary complex or from the sediments below the décollement. Fluids with similar low-chloride concentrations are also associated with zones of fluid expulsion in other accretionary prisms, such as the northern Barbados accretionary transect and the sediments in the active margin off Peru.

5 . Though perhaps the major input of fluids stem from the deeper sediment sections, there is evidence for some fluid input along the zone of décollement, with origins from within the accreted sediment sections.

\section{ACKNOWLEDGMENTS}

This manuscript has benefited from reviews by Drs. John Edmond and Russell McDuff. We are particularly grateful to Dr. Linda Bonnell for her thorough, critical commentary. This research was supported by JOI-USSAC (JMG, MK) and by the Ministry of Education, Science, and Culture of Japan (TG).

\section{REFERENCES*}

Boulègue, J., Liyama, J.T., Charlou, J.L., and Jedwab, J., 1987. Nankai Trough, Japan Trench and Kuril trench: geochemistry of fluid samples by submersible "Nautile." Earth Planet. Sci. Lett., 83:362 - 375.

Bray, C.J., and Karig, D.E., 1985. Porosity of sediments in accretionary prisms, and some implications for dewatering processes. J. Geophys. Res., 90:768778.

, 1986. Physical properties of sediments from the Nankai Trough, Deep Sea Drilling Project Leg 87A, Sites 582 and 583. In Kagami, H., Karig, D.E., Coulbourn, W.T., et al., Init. Repts. DSDP, 87: Washington (U.S. Govt. Printing Office), 827-842.

Burst, J.F., 1979. Diagenesis of Gulf Coast clayey sediments and its possible relation to petroleum migration. AAPG Bull., 53:73-93.

Foucher, J.P., LePichon, X., Lallemant, S., Hobart, M.A., Henry, P., Benedetti, M., Westbrook, G.K., and Langseth, M.G., 1990. Heat flow, tectonics, and fluid circulation at the toe of the Barbados Ridge accretionary prism. $J$. Geophys. Res., 95:8859-8868.

Fowler, S.R., White, R.S., and Louden, K.E., 1985. Sediment dewatering in the Makran accretionary prism. Earth Planet. Sci. Lett., 75:427-438.

* Abbreviations for names of organizations and publication titles in ODP reference lists follow the style given in Chemical Abstracts Service Source Index (published by American Chemical Society).
Gamo, T., Sakai, H., Ishibashi, J., Shitashima, K., and Boulegue, J., 1992. Methane, ethane, and total inorganic carbon in fluid samples taken during the 1989 Kaiko-Nankai project. Earth Planet. Sci. Lett., 109:383-390.

Gieskes, J.M., Blanc, G., Vrolijk, P., Elderfield, H., and Barnes, R., 1990. Interstitial water chemistry - major constituents. In Moore, J.C., Mascle, A., et al.,Proc. ODP, Sci.Results, 110: College Station, TX (Ocean Drilling Program), 155-178.

Gieskes, J.M., Blanc, G., Vrolijk, P., et al., 1989. Hydrogeochemistry in the Barbados Accretionary Complex: Leg 110 ODP. Palaeogeogr., Palaeoclimatol., Palaeoecol., 71:83-96.

Gieskes, J.M., Elderfield, H., Lawrence, J.R., Johnson, J., Meyers, B., and Campbell, A., 1982. Geochemistry of interstitial waters and sediments, Leg 64, Gulf of California. In Curray, J.R., Moore, D.G., et al., Init. Repts. DSDP, 64 (Pt. 2): Washington (U.S. Govt. Printing Office), 675-694.

Gieskes, J.M., Johnston, K., and Boehm, M., 1985. Interstitial water studies, Leg 66. In von Huene, R., Aubouin, J., et al., Init. Repts. DSDP, 84: Washington (U.S. Govt. Printing Office), 961-967.

Gieskes, J.M., Vrolijk, P., and Blanc, G., 1990. Hydrogeochemistry of the Northern Barbados Accretionary Complex Transect: ODP Leg 110. J. Geophys. Res., 95:8809-8818.

Harrison, W.E., Hesse, R., and Gieskes, J.M., 1982. Relationship between sedimentary facies and interstitial water chemistry of slope, trench, and Cocos plate sites from the Middle America Trench transect, active margin off Guatemala, Deep Sea Drilling Project Leg 67. In Aubouin, J., von Huene, R., et al., Init. Repts. DSDP, 67: Washington (U.S. Govt. Printing Office), 603-616.

Hesse, R., Lebel, J., and Gieskes, J.M., 1985. Interstitial water chemistry of gas-hydrate-bearing sections on the Middle America Trench slope, Deep Sea Drilling Project Leg 84 . In von Huene, R., Aubouin, J., et al., Init. Repts. DSDP, 84: Washington (U.S. Govt. Printing Office), 727-737.

Kagami, H., Karig, D.E., Coulbourn, W.T., et al., 1986. Init. Repts. DSDP, 87: Washington (U.S. Govt. Printing Office).

Karig, D.E., Ingle, J.C., Jr., et al., 1975. Init. Repts. DSDP, 31: Washington (U.S. Govt. Printing Office).

Kastner, M., Elderfield, H., and Martin, J.B., 1991. Fluids in convergent margins: what do we know about their composition, origin, role in diagenesis and importance for oceanic chemical fluxes? Philos. Trans. R. Soc. London A, 335:243-259.

Kastner, M., Elderfield, H., Martin, J.B., Suess, E., Kvenvolden, K.A., and Garrison, R.E., 1990. Diagenesis and interstitial-water chemistry at the Peruvian continental margin-major constituents and strontium isotopes. In Suess, E., von Huene, R., et al., Proc. ODP, Sci. Results, 112: College Station, TX (Ocean Drilling Program), 413-440.

Kastner, M., and Gieskes, J.M., 1976. Interstitial water profiles and sites of diagenetic reactions, Leg 35, DSDP, Bellingshausen Abyssal Plain. Earth Planet. Sci. Lett., 33:11-20.

Kawahata, H., Fujioka, K., and Ishizuka, T., 1986. Sediments and interstitial water at Sites 582 and 584, the Nankai Trough and the Japan Trench landward slope. In Kagami, H., Karig, D.E., Coulbourn, W.T., et al., Init. Repts. DSDP, 87: Washington (U.S. Govt. Printing Office), 865-875.

Kulm, L.D., Suess, E., Moore, J.C., Carson, B., Lewis, B.T., Ritger, S.D., Kadko, D.C., Thornburg, T.M., Embley, R.W., Rugh, W.D., Massoth, G.J., Langseth, M.G., Cochrane, G.R., and Scamman, R.L., 1986. Oregon subduction zone: venting, fauna, and carbonates. Science, 231:561-566.

LePichon, X., Henry, P., and Lallement, S., 1990. Water flow in the Barbados accretionary complex. J. Geophys. Res., 95:8945-8967.

LePichon, X., Iiyama, T., Boulègue, J., Charvet, J., Faure, M., Kano, K., Lallemant, S., Okada, H., Rangin, C., Taira, A., Urabe, T., and Uyeda, S., 1987. Nankai Trough and Zenisu Ridge: a deep-sea submersible survey. Earth Planet. Sci. Lett., 83:285-299.

Manheim, F.T., and Sayles, F.L., 1974. Composition and origin of interstitial waters of marine sediments based on deep sea drill cores. In Goldberg, E.D. (Ed.), The Sea (Vol. 5): New York (Wiley Interscience), 527-568.

Matsuhisa, Y., and Matsumoto, R., 1985. Oxygen isotope ratios of interstitial waters from the Nankai Trough and the Japan Trench, Leg 87. In Kagami, H., Karig, D.E., Coulbourn, W.T., et al., Init. Repts. DSDP, 87: Washington (U.S. Govt. Printing Office), 853-856.

Moore, J.C., and Biju-Duval, B., 1984. Tectonic synthesis, Deep Sea Drilling Project Leg 78A: structural evolution of offscraped and underthrust sediment, northern Barbados Ridge complex. In Biju-Duval, B., Moore, J.C., et al., Init. Repts. DSDP, 78A: Washington (U.S. Govt. Printing Office), 601-621.

Perry, E., and Hower, J., 1970. Burial diagenesis in Gulf Coast pelitic sediments. Clays Clay Miner., 18:165-177. 
Ritger, S., Carson, B., and Suess, E., 1987. Methane-derived authigenic carbonates formed by subduction-induced pore water expulsion along the Oregon/Washington margin. Geol. Soc. Am. Bull., 48:147-156.

Screaton, E.J., Wuthrich, D.R., and Dreiss, S.J., 1990. Permeabilities, fluid presssures, and flow rates in the Barbados Ridge Complex. J. Geophys. Res., 95:8997-9007.

Shi, Y., and Wang, C.-Y., 1985. High pore pressure generation in sediments in front of the Barbados Ridge Complex. Geophys. Res. Lett., 12:773-776.

, 1988. Generation of high pore pressures in accretionary prisms: inferences from the Barbados Subduction Complex. J. Geophys. Res., 93:8893-8909.

Swinbanks, D., 1985. Deep Sea clams: new find near Japan's coast. Nature, 316:475.

Taira, A., Hill, I., Firth, J.V., et al., in press. Proc. ODP, Init. Repts., 131: College Station, TX (Ocean Drilling Program).

von Huene, R., and Scholl, D.W., 1991. Observations at convergent margins concerning sediment subduction, subduction erosion, and the growth of the continental crust. Rev. Geophys., 29:279-316.
Vrolijk, P., Chambers, S.R., Gieskes, J.M., and O'Neil, J.R., 1990. Stable isotope ratios of interstitial fluids from the Northern Barbados Accretionary Prism, ODP Leg 110. In Moore, J.C., Mascle, A., et al., Proc. ODP, Sci. Results, 110: College Station, TX (Ocean Drilling Program), 189-205.

Vrolijk, P., Fisher, A., and Gieskes, J., 1991. Geochemical and geothermal evidence for fluid migration in the Barbados accretionary prism (ODP Leg 110). Geophys. Res. Lett., 18:947-950.

White, S., 1975. Interstitial water studies leg 31. In Karig, D.E., Ingle, J.C., Jr., et al., Init. Repts. DSDP, 31: Washington (U.S. Govt. Printing Office), 639-653.

Yeh, H.W., and Savin, S.M., 1977. Mechanisms of burial metyamorphism of argillaceous sediments: 3. O-isotope evidence. Geol. Soc. Am. Bull., 88:1321-1330.

Date of initial receipt: 24 March 1992

Date of acceptance: 7 October 1992

Ms 131SR-133

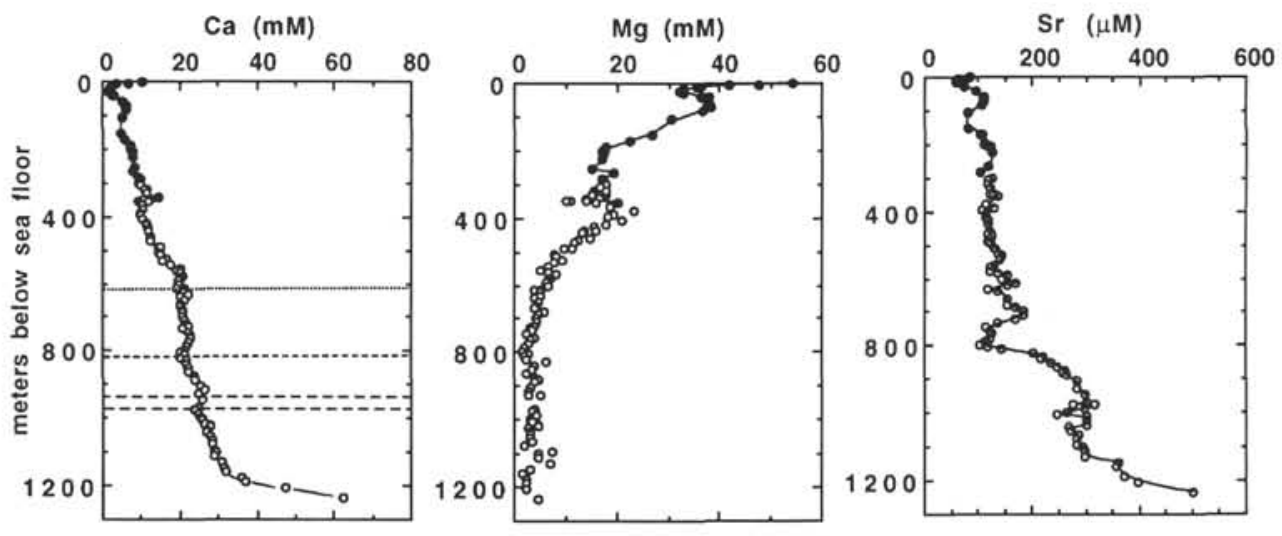

Figure 9. Alkaline earths in interstitial waters, Site 808. Closed circles: 808A and -B; open circles: 808C; horizontal lines as in Figure 6. 

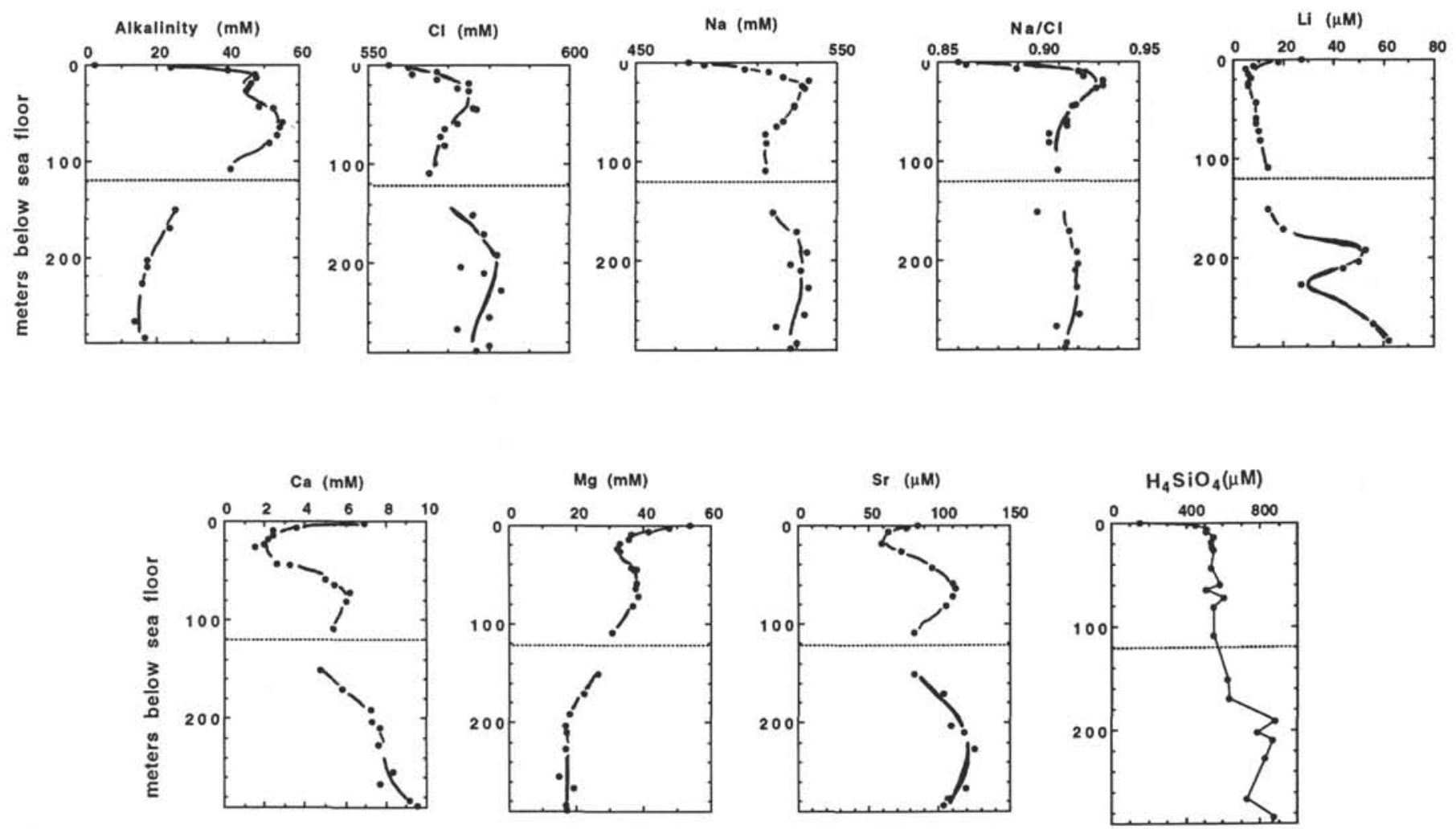

Figure 10. Interstitial water data, Holes $808 \mathrm{~A}$ and $808 \mathrm{~B}$. Dotted line separates $808 \mathrm{~A}$ and $-\mathrm{B}$.
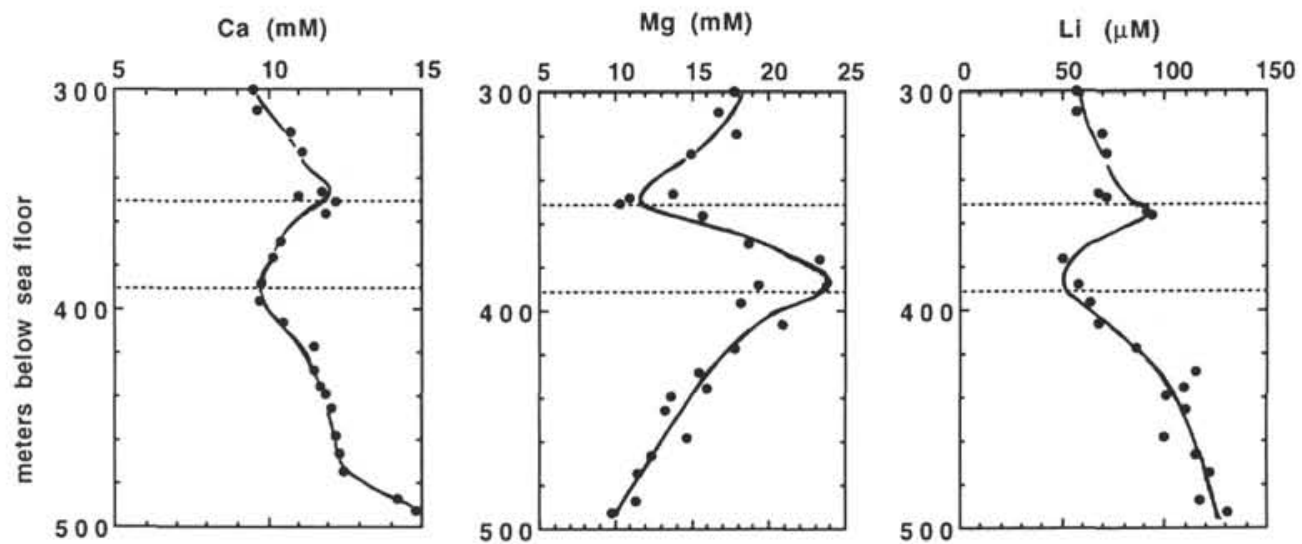

Figure 11. Distribution of pore water constituents calcium, magnesium, and lithium in zone of recent thrust fault Hole $808 \mathrm{C}$. Dashed lines represent boundaries to thrust fault zone. 


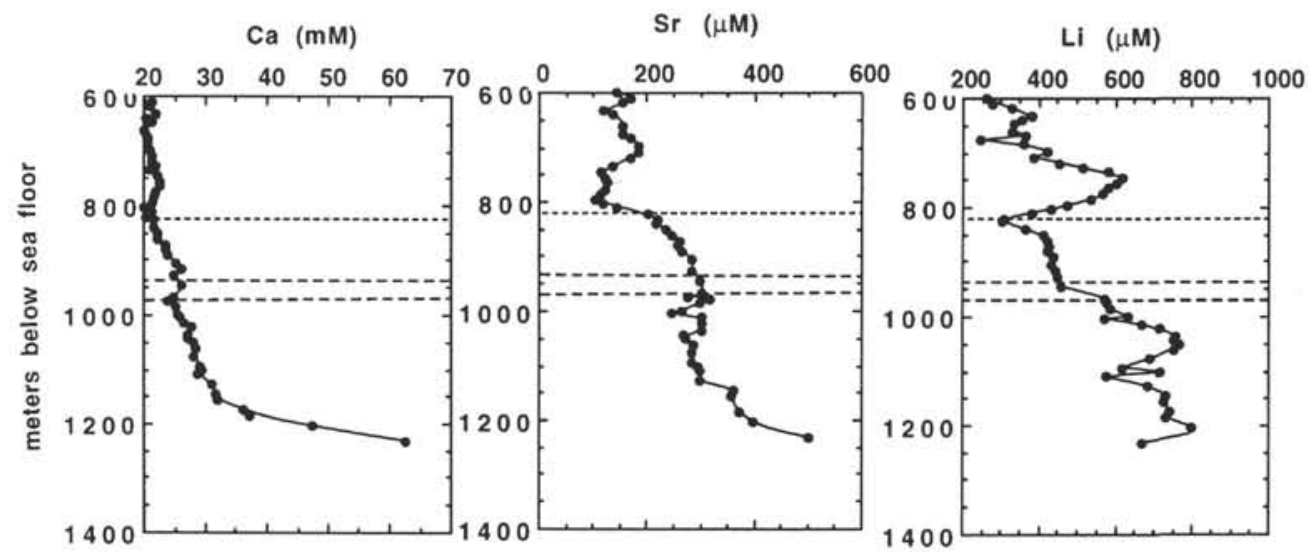

Figure 12. Distribution of calcium, strontium, and lithium in Shikoku Basin sediments. Upper dashed line: transition to lower Shikoku Basin sediments; lower two dashed lines delineate boundaries of décollement zone.
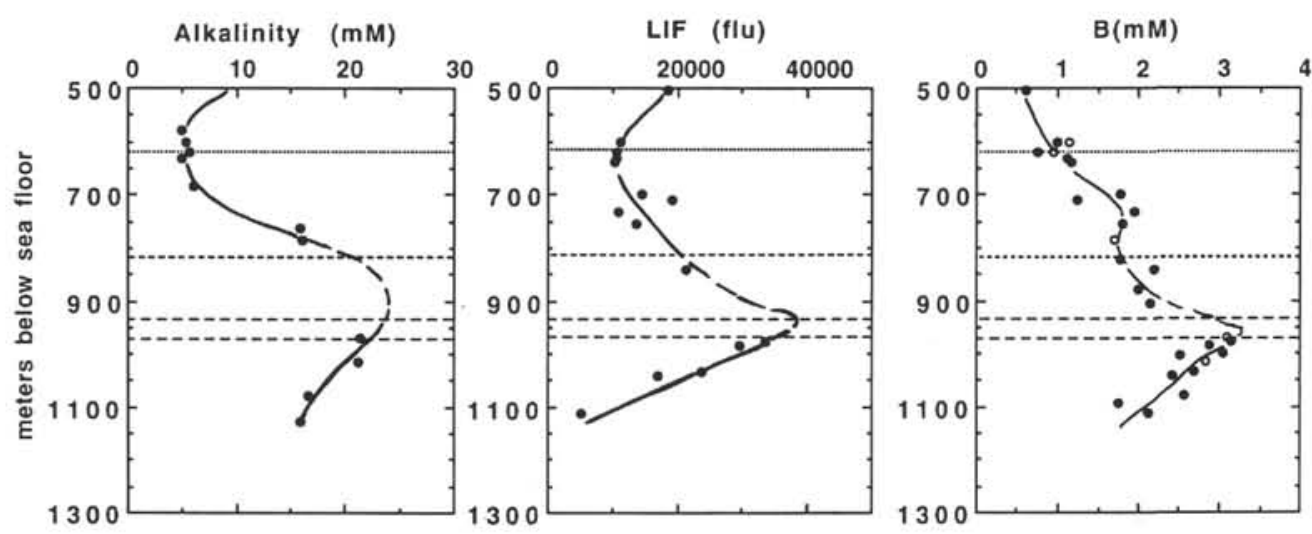

Figure 13. Distribution of alkalinity, boron, and laser-induced fluorescence of organic matter (LIF), Site 808. Note maxima around the zone of décollement. Horizontal lines as in Figure 6. 